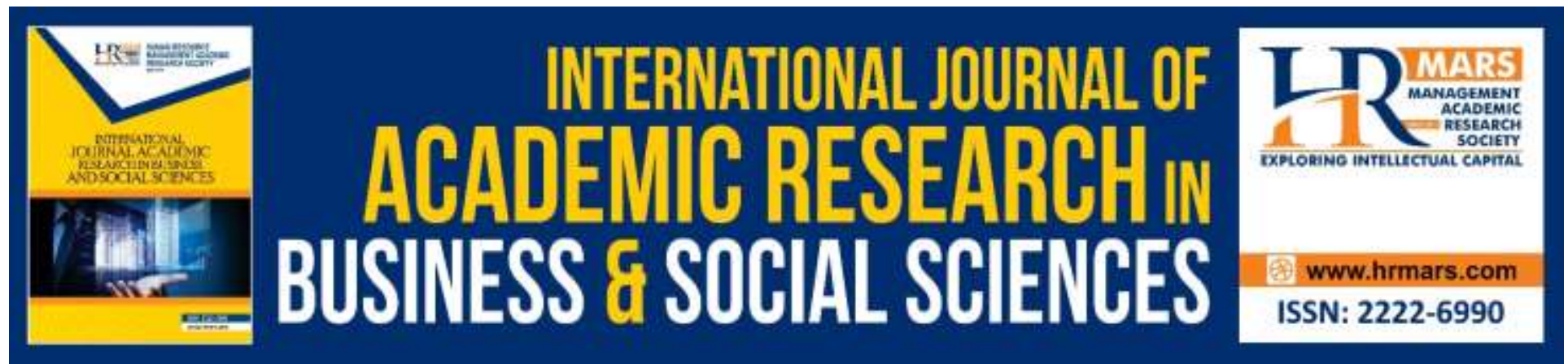

\title{
Impact of Strategic Thinking on High Performance Work Practices
}

\section{Badar Saif Alhatmi}

To Link this Article: http://dx.doi.org/10.6007/IJARBSS/v10-i5/7182

DOI:10.6007/IJARBSS/v10-i5/7182

Received: 10 March 2020, Revised: 12 April 2020, Accepted: 23 April 2020

Published Online: 07 May 2020

In-Text Citation: (Alhatmi, 2020)

To Cite this Article: Alhatmi, B. S. (2020). Impact of Strategic Thinking on High Performance Work Practices. International Journal of Academic Research in Business and Social Sciences, 10(5), 157-170.

Copyright: @ 2020 The Author(s)

Published by Human Resource Management Academic Research Society (www.hrmars.com)

This article is published under the Creative Commons Attribution (CC BY 4.0) license. Anyone may reproduce, distribute, translate and create derivative works of this article (for both commercial and non-commercial purposes), subject to full attribution to the original publication and authors. The full terms of this license may be seen

at: $\underline{\text { http://creativecommons.org/licences/by/4.0/legalcode }}$

Vol. 10, No. 5, 2020, Pg. 157 - 170

http://hrmars.com/index.php/pages/detail/IJARBSS

JOURNAL HOMEPAGE

Full Terms \& Conditions of access and use can be found at http://hrmars.com/index.php/pages/detail/publication-ethics 


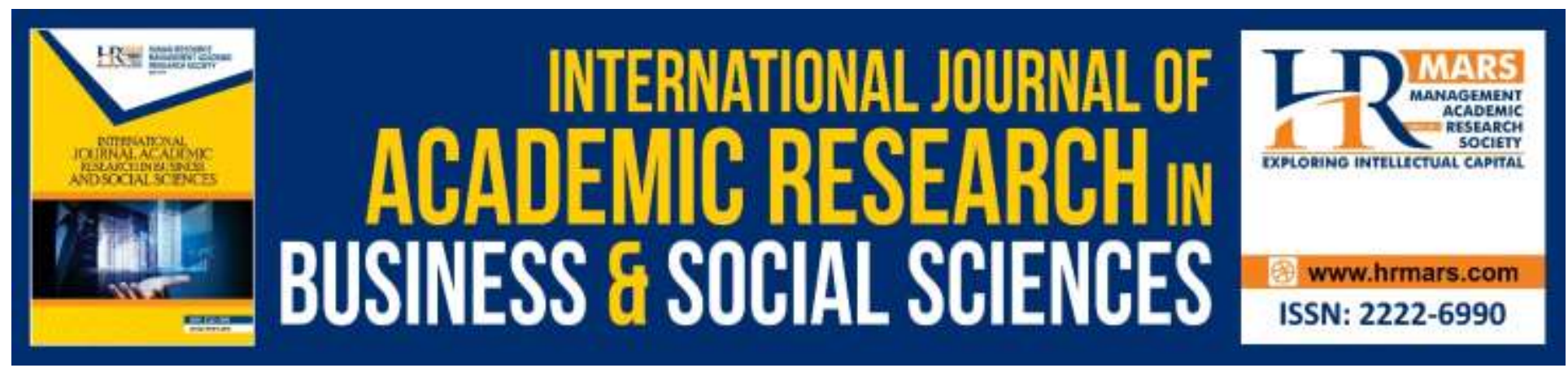

\title{
Impact of Strategic Thinking on High Performance Work Practices
}

\author{
Badar Saif Alhatmi \\ Strategic Management, Mutah University, Jordan \\ Email: alhatmib7@gmail.com
}

\begin{abstract}
Thinking give a more noteworthy open door for organizations to plan and arrange business activities to succeed, accordingly, this study seeks to define the role of strategic thinking on high performance work practices. The research sample comprised of $270 \mathrm{employees,} \mathrm{were} 251$ questionnaires valid for statistical analysis, adopting the descriptive approach. Questionnaire was used to measure the strategic thinking impact on high performance work practices. The study concluded that there was a high using level of strategic thinking, including its dimensions, and that the same applies to the level of high performance work practices and its dimensions. In addition, there was a statistically significant correlation between strategic thinking and high performance work practices. In light of the aforementioned results, the study recommended company to use different strategies seize opportunities about employees to employ it to promote performance and improve it.

Keywords: Strategic Thinking, HPWP, Extensive Training, Internal Mobility, Employment Security, and Selective Staffing.
\end{abstract}

\section{Introduction}

There is as yet a far-reaching understanding that strategic thinking is significant for the productive administration of firms, yet it is regularly missing or if nothing else lacking (Bonn, 2001; Liedtka, 1998). The hole practically speaking is trailed by verifiable disarray of the idea among the two researchers and experts, where the terms strategic thinking, strategic arranging, and strategic administration are utilized reciprocally (Mintzberg, 1994). Goldman and Casey (2010) state: "notwithstanding the deficiency in the writing with respect to strategic thinking, there is a hole practically speaking. Top pioneers' nonattendance of strategic thinking has been recognized as a significant depreciator of firm execution in concentrates across enterprises and nations (Bonn, 2001; Essery, 2002; Mason, 1986; Zabriskie and Huellmantel, 1991). There is a worry that this hole will proceed: Bonn (2005) noticed that strategic thinking was distinguished by a board of specialists as one of the 10 most basic zones for future administration research. Likewise, both administration and technique scholars have shown that strategic thinking is required at numerous authoritative levels." In this sense, Goldman et al (2015) contend that "In spite of the accord on 
the requirement for strategic thinking and the general guidance that it ought to be supported by associations, there is meager writing on what associations really do to support pioneers, administrators, and others utilized by the association build up their capacity to think strategically, how they do it, why they do it, and how much their endeavors are viable." On account of strategic dynamics, Eisenhardt and Zbaracki (1992) assert that: "Focal among strategic procedure issues is strategic dynamic. It is urgent in light of the fact that it includes those major choices which shape the course of a firm. During the previous 30 years, numerous analysts have perceived the centrality of the subject by handling issues in strategic and all the more by and large, hierarchical dynamic. However, a brisk assessment recommends that the character of the field takes after an 'insane blanket' of points of view (Aljawarneh \& Atan, 2018; Irtaimeh, et al, 2016).

The increasingly intensive examination uncovers a field dependent on developing ideal models and fragmented suspicions." For the situation of strategic arranging, Henry Mintzberg, perhaps the sharper creator portraying the manner in which this idea has been misjudged sets: "When strategic arranging showed up on the scene in the mid-1960s, corporate pioneers held onto it as "the one most ideal way" to devise and execute methodologies that would upgrade the seriousness of every specialty unit. Planning frameworks were required to deliver the best procedures just as bit by bit directions for doing those methodologies with the goal that the practitioners, the administrators of organizations, couldn't misunderstand them. As we currently know, arranging has not actually played out as expected." (Mintzberg, 1994) Through a writing audit, this paper exhibits inside different various investigations since 1985 that organizations do not have the right use of the corporate methodology in their training by a general misguided judgment of the distinctive procedure ideas. It further intends to introduce new bits of knowledge into strategic thinking and explain the relationship and the importance of these three distinct ideas of procedure thinking, arranging and dynamic adding to empowering a culture of strategic thinking and furthermore activating further investigations about the utilization of strategic thinking and its effect in business execution, particularly in times that claims for authoritative changes because of the need of maintainable improvement (Al-Jawarneh, 2016; Obeidat, 2019).

The paper begins by setting up the contrast between strategic arranging and strategic thinking and further build up every idea to at last adjust them to the strategic dynamic procedure. The content wraps up by investigating the present changes in the association's procedures because of manageability requests and how the reception of strategic thinking will be fundamental for future development and accomplishment of firms (Dionisio 2017; Al-Qudah et al, 2020).

Managing individuals is a dificult task particularly right now extraordinary market rivalry and expansion in a piece of the pie all around. This implies the 21st-century (HR) supervisor in a worldwide organization is probably going to be stood up to with the predicament of keeping an eye on empty situations with the ideal individuals. Organizations need representatives who can work in various social settings; which is essential for seeking after worldwide systems. Globalizing is important to defeat the weights from the present monetary emergency (Hossain et al., 2011) that is shaking the establishments of the world's most remarkable economies. High-performance work practices (HPWPs) is one method for guaranteeing that representatives are overseen adequately to turn out to be highly beneficial in the workplace. HPWPs have been the subject of philosophical discussion in most HR the executives writing for a long while. Subsequently, the point of this paper is to look at the nature, types, and adequacy of HPWPs in a business 
association utilizing both past and surviving writing with the expectation of revealing crisp bits of knowledge about the idea. The information and comprehension picked up from this investigation would without a doubt help the 21st century HR chief to settle on educated choices concerning representatives in associations. (Timiyo, 2014).

\section{Literature Review}

\section{Strategic Thinking}

Firms in the 21st Century face a wide cluster of complex open doors including, however not restricted to, worldwide market extension, creating inside and outside imaginative items and practices to stay serious just as working. This isn't constrained to global organizations, yet in addition to medium and little estimated organizations. Keeping up a serious edge in a worldwide, inventive and powerfully developing condition produces strain to rethink how business is led (Ulijn et al., 2000). Over various years, ranking directors have gotten progressively worried about the changing idea of their authoritative surroundings and how they can recognize and follow up on such changes in the earth (Davis, 2002; Malkawi, et al 2017; Al-Omari, et al., 2020). In any case, right now, results of progress are not constantly unsurprising and the earth is dynamic, making the identification of progress considerably more troublesome (Grewal and Tansuhaj, 2001).

The environment incorporates both inner factors, for example, the way of life of the association and individual qualities and convictions just as outside variables, for example, innovation, nature, enactment, and governmental issues. Morgan (1997) recommends both inside and outer variables should be considered with the end goal for associations to push ahead. Morgan contends that associations are political frameworks in which all individuals seek after their own advantages (in view of their own qualities and convictions) just as impacted by outside variables, for example, the commercial center, innovation, and society. It is the job of strategic scholars to comprehend both the interior and outside components and their effect on the eventual fate of the association. Strategic thinking has been looked into in both the administration and mental writing with the administration writing concentrating on the procedure of strategic thinking and settling on strategic choices (Mintzberg, 1994; Drejer et al, 2005; (Aljawarneh \& Al-Omari, 2018). while the mental writing has concentrated on factors influencing strategic thinking and dynamic (Hambrick and Mason, 2001; Pant, 1998). This audit gives a diagram of both the methodologies and recognizes the significance of considering both the methodologies together so comprehension of what settles on a decent strategic chief can be looked for. This would help associations in creating criteria in which to evaluate individual strategic dynamic viability (Steptoe-Warren et al., 2011).

\section{High Performance Work Practices}

High performance work practices (HPWPs) are definitely not another worldview in HR the board (HRM) in light of the fact that overseeing individuals adequately existed quite a while in the past. Obviously, until this point, there is no exact meaning of what high-performance work practices are, and the particular segments that make up the practices stay flawed (Lloyd and Payne, 2004). This prompted the end drawn by certain researchers that the exact meaning of HPWPS is dependent upon constant debatell (Sung et al., 2005). Regardless of these broadly held feelings, the term HPWPs has similar implications with what a few creators like Huselid and Rau (1997), 
Ramsay et al. (2000), Patel and Conklin (2012) allude to as high-performance work frameworks (HPWS), others like Purcell (2006) allude to it as high duty the executives (HCM) while, Delaney and Huselid (1996) utilize dynamic HRM practices.

A decent number of researchers (Kalleberg et al., 2006) likewise utilize the term highperformance work associations (HPWOs). Regardless of this disarray, the basic destinations and standards behind these wordings are the equivalent. Subsequently, HPWPs can be characterized as those practices which Human Resources chiefs embrace so as to improve representatives' performance in associations (Aston and Sung, 2002; Saffar, \& Obeidat, 2020). Tamkin (2004) characterized HPWPS as those formalized systems used to test the adequacy of HR on firms' performance. While in the perspectives of Sung et al. (2005) HPWPs are a set of corresponding work practices covering three general classes which incorporate; high representative contribution practices, human asset practices, prize and responsibility practices\| (Sung et al., 2005 p. 4) in a business association. Patel and Conklin (2012) portrayed high-performance work practices as those set of worker the board practices that emphatically influence representatives' perspectives, inspiration, and performance\| (Patel and Conklin, 2012 referring to Sels et al., 2006). The ramifications of these definitions propose that HPWPs are those arrangements of HR practices that are either fit for improving workers' aptitudes or propelling them to turn out to be increasingly gainful (Huselid, 1995). The model of the study includes an independent variable which is Strategic Thinking. HPWPis the dependent variable of this study and the model below illustrate it.

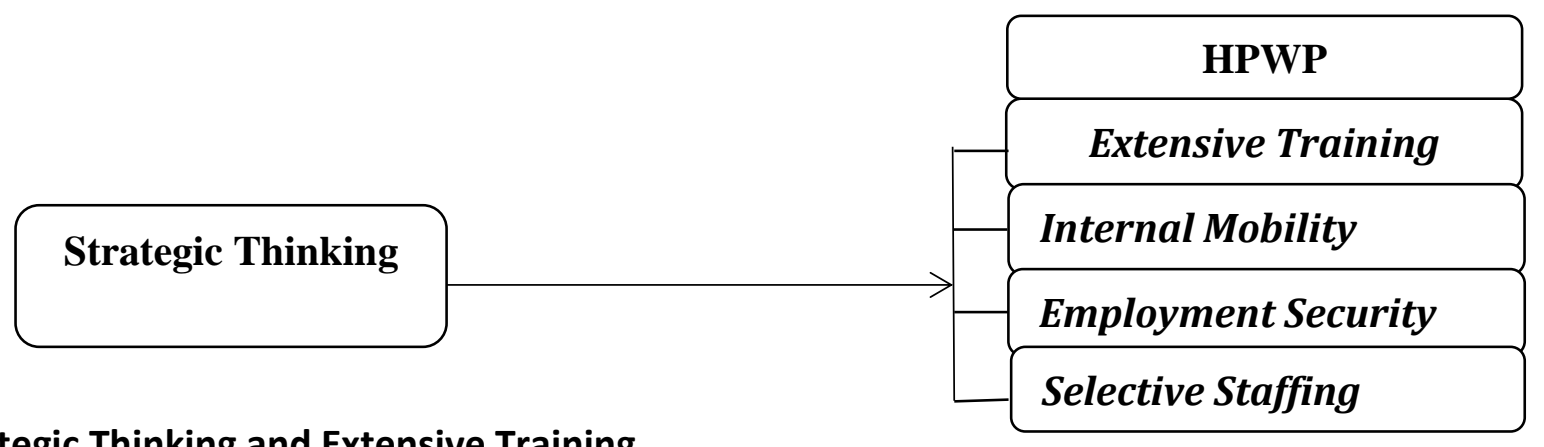

\section{Strategic Thinking and Extensive Training}

The environment incorporates both inner factors, for example, the way of life of the association and individual qualities and convictions just as outside variables, for example, innovation, nature, enactment, and governmental issues. Morgan, (1997) recommends both inside and outer variables should be considered with the end goal for associations to push ahead. Morgan contends that associations are political frameworks in which all individuals seek after their own advantages (in view of their own qualities and convictions) just as impacted by outside variables, for example, the commercial center, innovation, and society. It is the job of strategic scholars to comprehend both the interior and outside components and their effect on the eventual fate of the association. Strategic thinking has been looked into in both the administration and mental writing with the administration writing concentrating on the procedure of strategic thinking and settling on strategic choices (Mintzberg, 1994; Drejer et al, 2005; Obeidat \& Otibi, 2015; Al-Omari, et al., 2018). To concoct the ideal information, aptitudes, and capacities from workers to perform well at their place of work requires legitimate preparing programs that may in like manner affect representative inspiration and responsibility. Representatives can either manufacture or break 
their organization's notoriety for being admirable as a benefit. In addition, they regulate the greater part of the exercises which can impact client satisfaction, the nature of the item and the occasion. As per G.P. Nunvi (2006), preparing programs are coordinated towards keeping up and improving the present place of employment execution while advancement looks to improve aptitudes for future occupations.

H1: There is relationship between Strategic Thinking and Extensive Training.

\section{Strategic Thinking \& Internal Mobility}

firms in the 21st Century face a wide cluster of complex open doors including, however not restricted to, worldwide market extension, creating inside and outside imaginative items and practices to stay serious just as working. This isn't constrained to global organizations, yet in addition to medium and little estimated organizations. Keeping up a serious edge in a worldwide, inventive and powerfully developing condition produces strain to rethink how business is led (Ulijn et al., 2000). Over various years, ranking directors have gotten progressively worried about the changing idea of their authoritative surroundings and how they can recognize and follow up on such changes in the earth (Davis, 2002; Al-Da'abseh, et al., 2018). In any case, right now, results of progress are not constantly unsurprising and the earth is dynamic, making the identification of progress considerably more troublesome (Grewal and Tansuhaj, 2001).

This article broadens an examination on representative versatility and firm performance are interlinked and the portability inside the association benefits the firm against the contenders the firm likewise needs to give workers who structure social capital which is destructive. Future work demonstrates that representative portability may helpful to the association's performance. This likewise says the positive advantage to the organization is essentially through outside social capital made by a worker who leaves the parent firm. Spellbinding examination \&correlation demonstrates the connection between coordinates \&competitor.

H2: There is relationship between Strategic Thinking and Internal Mobility.

\section{Strategic Thinking and Employment Security}

Morgan, (1997) recommends both inside and outer variables should be considered with the end goal for associations to push ahead. Morgan contends that associations are political frameworks in which all individuals seek after their own advantages (in view of their own qualities and convictions) just as impacted by outside variables, for example, the commercial center, innovation, and society. It is the job of strategic scholars to comprehend both the interior and outside components and their effect on the eventual fate of the association (Mahafzah et al., 2020). Strategic thinking has been looked into in both the administration and mental writing with the administration writing concentrating on the procedure of strategic thinking and settling on strategic choices (Mintzberg, 1994; Drejer et al, 2005) while the mental writing has concentrated on factors influencing strategic thinking and dynamic (Hambrick and Mason, 2001; Pant, 1998). Independent work incorporates a somewhat heterogeneous gathering of laborers. Bosses, claim account laborers, and different sorts of non-standard specialists, for example, 'autonomous specialists', 'contractors' and so on fall into the classification of independently employed. The above meaning of employment security doesn't make a difference to these independently employed specialists. Nor does it apply to the different sorts of 'non-standard' employment, 
where there is regularly nonattendance of any 'connection' with anyone manager. Measurably, these non-standard specialists are regularly taken to act naturally utilized.

H3: There is relationship between Strategic Thinking and Employment Security.

\section{Strategic Thinking \& Selective Staffing}

During the previous 30 years, numerous analysts have perceived the centrality of the subject by handling issues in strategic and all the more by and large, hierarchical dynamic. However, a brisk assessment recommends that the character of the field takes after an 'insane blanket' of points of view. The increasingly intensive examination uncovers a field dependent on developing ideal models and fragmented suspicions." For the situation of strategic arranging, Henry Mintzberg, perhaps the sharper creator portraying the manner in which this idea has been misjudged sets: "When strategic arranging showed up on the scene in the mid-1960s, corporate pioneers held onto it as "the one most ideal way" to devise and execute methodologies that would upgrade the seriousness of every specialty unit.

The surveys of enrollment and choice practices both recognized a requirement to explore indicating specialty unit esteem/hierarchical effect. This is fascinating given the most essential staffing suspicion, one depicted in almost every reading material composed regarding the matter, is that selecting and enlisting better representatives adds to authoritative adequacy. In the event that it doesn't, at that point why put resources into staffing? Be that as it may, there is, in reality, minimal immediate, exact proof testing this supposition (e.g., Ployhart, 2004; Saks, 2005; Taylor and Collins, 2000; Alwagfi et al., 2020). Utility examination might be useful to assess these impacts, however, they just gauge that is constrained to money related results and are oftentimes limited by supervisors (Schneider et al., 2000). Experts and HR administrators frequently need to work out positively past legitimacy (and even utility/money related appraisals) to put forth a defense that staffing increases the value of the firm.

H4: There is relationship between Strategic Thinking and Selective Staffing

\section{Methodology}

This study is one of the field studies that use analytical descriptive method, using the applied method that aims at collecting and analyzing data, and testing hypotheses.

\section{The Study Population}

The study community represented all supervisory and leadership positions in the General Authority for Water in the Sultanate of Oman, which numbered (270) individuals, as they represent decision-makers in these institutions. This study will depend on the method of comprehensive survey in selecting the study sample through distributing the questionnaire to all the vocabulary of the study community, so that the study sample is equal to its society, that is (270) managers who belong to the higher, middle and lower departments in the authority in the Sultanate of Oman, where the researcher retrieved 259 questionnaires, and retrieved (8) Questionnaires that are not valid for analysis, and for a final total of (251) to be completed.

\section{Reliability and Validity}

To verify the validity of the study tool, the questionnaire was presented to a group of arbitrators with expertise and experience from members of the teaching staff in the administration 
departments in the faculties of economics in a number of Jordanian and Omani universities to judge the extent of their validity, and the arbitrators were asked to judge the validity of the content of the paragraphs, And its affiliation with the fields for which it was put in place, making sure that they were formulated, and amending or deleting some of them. To test the reliability, the Cronbach Alpha factor was used for internal consistency. Results like this the studies are (0.60) and Table (1) shows the stability coefficients of the study variables.

Table1 Coefficient of internal consistency

\begin{tabular}{lc}
\hline Variables & Cronbach's Alpha \\
\hline Strategic Thinking & .768 \\
Extensive Training & .873 \\
Internal Mobility & .981 \\
Employment Security & .760 \\
Incentive Reward & .899 \\
Selective Staffing & .921 \\
High Performance Work Practices & .897 \\
All fields of study & .901 \\
\hline
\end{tabular}

Description of the study variables

Table 2 the mean and standard deviation

\begin{tabular}{lccc}
\hline Variables & mean & SD & Level \\
\hline Strategic Thinking & 4.231 & $\mathbf{0 . 7 8 3}$ & High \\
Extensive Training & 4.212 & 0.871 & High \\
Internal Mobility & 3.324 & 0.890 & Moderate \\
Employment Security & 3.981 & 0.793 & High \\
Incentive Reward & 4.290 & 0.768 & High \\
Selective Staffing & 3.562 & 0.853 & Moderate \\
High Performance Work Practices & $\mathbf{3 . 8 7 7}$ & $\mathbf{0 . 8 5 3}$ & High \\
\hline
\end{tabular}

From the above table it is clear that the mean of the strategic thinking variable reached (4.231) at a high level, while the mean dimensions of high-performance work practices ranged between (3.324-4.290) at a high level.

Test of the Study Hypotheses

Test hypotheses Hypothesis 1: There a relationship between Strategic Thinking and Extensive Training.

\begin{tabular}{|c|c|c|c|c|c|c|c|c|c|c|}
\hline \multirow{2}{*}{$\begin{array}{l}\text { Dependent } \\
\text { Variable }\end{array}$} & \multirow{2}{*}{$\mathbf{R}$} & \multirow{2}{*}{$\mathbf{R}^{2}$} & \multirow{2}{*}{$\mathbf{F}$} & \multirow{2}{*}{ DF } & \multirow{2}{*}{ Sig** } & \multicolumn{5}{|c|}{ Regression coefficient } \\
\hline & & & & & & IV & $\beta$ & $\begin{array}{l}\text { Std. } \\
\text { Error }\end{array}$ & $\mathrm{t}$ & $\begin{array}{l}\text { Sig* } \\
*\end{array}$ \\
\hline & 0.59 & 0.43 & 97. & 1 & 0.002 & Strateg & 0.80 & 0.093 & 8.981 & 0.00 \\
\hline $\begin{array}{l}\text { Extensive } \\
\text { Training }\end{array}$ & 2 & 5 & 78 & 250 & & $\begin{array}{c}\text { ic } \\
\text { Thinkin }\end{array}$ & 3 & & & 2 \\
\hline & & & & 251 & & g & & & & \\
\hline
\end{tabular}


The results of the table above show that the simple regression test for the effect of Strategic Thinking and Extensive Training was statistically significant 0.05 , where the calculated value of $F$ was equal to (97.78) and the level of significance (Sig $=0.000)$. The value of the correlation coefficient was (0.592), which is evidence of a positive relationship between the two variables. The determination coefficient has reached (0.435), meaning that the independent variable explains (43.5\%) of the changes in the dependent variable. In addition, the value of the degree $\beta$ has reached (0.803), which is statistically significant, where the calculated value of $t$ has (8.981) significant at the level of statistical significance 0.05 , Hypothesis 2: There is no relationship between Strategic Thinking and Internal Mobility

\begin{tabular}{|c|c|c|c|c|c|c|c|c|c|c|}
\hline \multirow[b]{2}{*}{$\begin{array}{l}\text { Dependent } \\
\text { Variable }\end{array}$} & \multirow{2}{*}{$\mathbf{R}$} & \multirow{2}{*}{$\mathbf{R}^{2}$} & \multirow{2}{*}{$\mathbf{F}$} & \multirow{2}{*}{ DF } & \multirow{2}{*}{$\begin{array}{l}\text { Sig } \\
* *\end{array}$} & \multicolumn{5}{|c|}{ Regression coefficient } \\
\hline & & & & & & IV & $\beta$ & $\begin{array}{l}\text { Std. } \\
\text { Error }\end{array}$ & $\mathrm{t}$ & $\begin{array}{l}\text { Sig* } \\
*\end{array}$ \\
\hline \multirow{5}{*}{$\begin{array}{l}\text { Internal } \\
\text { Mobility }\end{array}$} & 0.56 & 0.3 & 96.231 & 1 & \multirow{5}{*}{$\begin{array}{l}0.0 \\
00\end{array}$} & \multirow{5}{*}{$\begin{array}{l}\text { Strategic } \\
\text { Thinking }\end{array}$} & 0.85 & 0.099 & 9.789 & 0.00 \\
\hline & 9 & 29 & & 25 & & & \multirow[t]{4}{*}{6} & & & \multirow[t]{4}{*}{0} \\
\hline & & & & 0 & & & & & & \\
\hline & & & & 25 & & & & & & \\
\hline & & & & 1 & & & & & & \\
\hline
\end{tabular}

The results of the table above show that the Strategic Thinking and Internal Mobility regression test is significant with a statistical significance of 0.05 , where the calculated value of $F$ is equal to $(96.231)$ and the level of significance (Sig $=0.000)$. The value of the correlation coefficient was (0.569), which indicates evidence of a positive relationship between the two variables. The determination coefficient has reached (0.329), meaning that the independent variable explains (32.9\%) of the changes in the dependent variable. In addition, the value of the degree $\beta$ has reached (0.856), which is statistically significant, where the calculated value of $t$ has (9.789) significant at the level of statistical significance 0.05 .

Hypothesis 3: There is no relationship between Strategic Thinking and Employment Security.

\begin{tabular}{|c|c|c|c|c|c|c|c|c|c|c|}
\hline \multirow{2}{*}{$\begin{array}{l}\text { Depende } \\
\text { nt } \\
\text { Variable }\end{array}$} & \multirow{2}{*}{$\mathbf{R}$} & \multirow{2}{*}{$\mathbf{R}^{2}$} & \multirow{2}{*}{$\mathbf{F}$} & \multirow{2}{*}{ DF } & \multirow{2}{*}{$\begin{array}{l}\text { Sig* } \\
*\end{array}$} & \multicolumn{5}{|c|}{ Regression coefficient } \\
\hline & & & & & & IV & $\boldsymbol{\beta}$ & $\begin{array}{l}\text { Std. } \\
\text { Error }\end{array}$ & $\mathrm{t}$ & $\begin{array}{c}\text { Sig* } \\
*\end{array}$ \\
\hline Employm & 0.56 & 0.3 & 146. & 1 & 0.00 & & 0.8 & 0.075 & 11.901 & 0.00 \\
\hline $\begin{array}{l}\text { ent } \\
\text { Security. }\end{array}$ & 0 & 99 & 944 & $\begin{array}{l}250 \\
251\end{array}$ & 1 & Thinking & 31 & & & 1 \\
\hline
\end{tabular}

The results of the above table show that the simple regression and Employment Security Strategic Thinking were statistically significant 0.05 , where the calculated value of $F$ is equal to (146.944), and the level of significance (Sig $=0.001)$, and the value of correlation coefficient $(0.560)$, which is evidence of a positive relationship between The two variables. Also, the determination coefficient has reached (0.399), meaning that the independent variable explains (39.9\%) of the changes in the dependent variable, in addition to that the value of the degree of $\beta$ has reached (0.831) which is statistically significant, where the value of $t$ calculated with it (11.901) significant at the level of statistical significance 0.05 . 
INTERNATIONAL JOURNAL OF ACADEMIC RESEARCH IN BUSINESS AND SOCIAL SCIENCES

Vol. 10, No. 5, May, 2020, E-ISSN: 2222-6990 @ 2020 HRMARS

Hypothesis 4: There is no relationship between Strategic Thinking and Selective Staffing

\begin{tabular}{|c|c|c|c|c|c|c|c|c|c|c|}
\hline \multirow[b]{2}{*}{$\begin{array}{l}\text { Dependent } \\
\text { Variable }\end{array}$} & \multirow{2}{*}{$\mathbf{R}$} & \multirow{2}{*}{$\mathbf{R}^{2}$} & \multirow{2}{*}{$\mathbf{F}$} & \multirow{2}{*}{ DF } & \multirow{2}{*}{$\begin{array}{l}\text { Sig* } \\
*\end{array}$} & \multicolumn{5}{|c|}{ Regression coefficient } \\
\hline & & & & & & IV & $\beta$ & $\begin{array}{l}\text { Std. } \\
\text { Error }\end{array}$ & $\mathrm{t}$ & $\begin{array}{l}\text { Sig* } \\
*\end{array}$ \\
\hline $\begin{array}{l}\text { Selective } \\
\text { Staffing }\end{array}$ & $\begin{array}{l}0.56 \\
3\end{array}$ & $\begin{array}{l}0.38 \\
7\end{array}$ & $\begin{array}{l}115.0 \\
94\end{array}$ & $\begin{array}{l}1 \\
250 \\
251\end{array}$ & $\begin{array}{l}0.00 \\
0\end{array}$ & $\begin{array}{l}\text { Strategic } \\
\text { Thinking }\end{array}$ & $\begin{array}{l}0.8 \\
70\end{array}$ & 0.092 & $\begin{array}{l}12.98 \\
3\end{array}$ & $\begin{array}{l}0.00 \\
0\end{array}$ \\
\hline
\end{tabular}

The results of the table above show that the simple regression of Strategic Thinking and Selective Staffing was statistically significant 0.05 , where the calculated value of $F$ is equal to (115.094), and the level of significance ( $\mathrm{Sig}=0.000)$, and the value of correlation coefficient $(0.563)$, which is evidence of a positive relationship between the two variables. The determination coefficient has reached (0.387), meaning that the independent variable explains (38.7\%) of the changes in the dependent variable. In addition, the value of the degree $\beta$ has reached $(0.870)$, which is statistically significant, where the value of the calculated thas (12.983) significant at the level of statistical significance (0.05).

\section{Conclusion}

At the end of this research work the researcher have come up with the conclusion based on the findings that Strategic thinking has a positive effect and correlation on all the dependent variables.

The researcher finds out that strategic thinking has a positive relationship with Extensive Training based on the findings in the first hypotheses development, then in the second hypotheses development it shows that strategic thinking has a relationship with Internal Mobility, hypotheses 3 posits that strategic thinking has a correlation with Employment Security then in the fourth and final hypotheses the researcher proves that strategic thinking has a relationship Selective Staffing. Therefore, all these findings then contribute to prove that strategic thinking influences High Performance Work Practices which most often results in a good and balanced work outputs by staffs of an organization. This finding is in line with the research of Ulijn et al., (2000) which states that firms in the 21st Century face a wide cluster of complex open doors including, however not restricted to, worldwide market extension, creating inside and outside imaginative items and practices to stay serious just as working. This isn't constrained to global organizations, yet in addition to medium and little estimated organizations. Keeping up a serious edge in a worldwide, inventive and powerfully developing condition produces strain to rethink how business is led and the research of (Mintzberg, 1994) which states that there is as yet a farreaching understanding that strategic thinking is significant for the productive administration of firms, yet it is regularly missing or if nothing else lacking (Bonn, 2001; Liedtka, 1998). The hole practically speaking is trailed by verifiable disarray of the idea among the two researchers and experts, where the terms strategic thinking, strategic arranging, and strategic administration are utilized reciprocally. The research of many other experienced scholars also agrees with the results, findings and conclusion of this research work.

\section{Major Findings}

Appelbaum (2015) High-performance work practices have been appeared to work in three unique manners: Cultivating the advancement of human capital, making a performance 
advantage for associations through procedures, for example, expanded worker ability improvement and improved customization by representatives in administration industries. Upgrading the inspiration and duty of representatives, making a hierarchical and work the board atmosphere that persuades and bolsters representative commitment in critical thinking and performance improvement and building authoritative social capital, which encourages information sharing and the coordination of work, and along these lines improves performance. Research in settings extending from state-funded schools to aircraft has shown the additional advantages to being acknowledged when work practices energize the concurrent advancement of human capital and social capital among representatives

\section{Recommendations}

The exploration proof that businesses, representatives, investors, and clients can all the while advantage from work rehearses that upgrade specialist inspiration, human capital, and social capital is vigorous over a wide scope of enterprises. Simultaneously, such practices can't be executed in a "cookbook" way however rather should be custom-made to specific businesses and work settings. The proof is obvious: accomplishing and supporting world-class levels of execution requires an incorporated way to deal with capital speculation, interest in and presentation of new advances, and usage of superior working environment rehearses custom fitted to the particular business and innovation. Appelbaum (2015) policymakers can bolster the advancement and boundless selection of such practices by connecting them legitimately to monetary or mechanical speculations that are made to help a reasonable way for financial development. To guarantee that elite work rehearses diffuse all the more comprehensively over the economy and produce benefits for the two bosses and representatives, we suggest that these endeavors be supported together by the Department of Commerce and the Department of Labor.

\section{Implementation}

The environment incorporates both inner factors, for example, the way of life of the association and individual qualities and convictions just as outside variables, for example, innovation, nature, enactment, and governmental issues. Both inside and outer variables should be considered with the end goal for associations to push ahead. Morgan contends that associations are political frameworks in which all individuals seek after their own advantages (in view of their own qualities and convictions) just as impacted by outside variables, for example, the commercial center, innovation, and society. Strategic thinking from our conclusion is seen as a tool that when implemented in any organization will lead a high level of inputs by workers and staffs which will definitely result in a good productive results and outputs in the firms. Strategic thinking when implemented in any institution will improve the educational level of the institution and therefore lead to the students doing well in all field of study, in same way if the government adopt the implementation of strategic thinking there will be better correlation between the governmental bodies and the people which will at the end lead to a better governance. 
INTERNATIONAL JOURNAL OF ACADEMIC RESEARCH IN BUSINESS AND SOCIAL SCIENCES

Vol. 10, No. 5, May, 2020, E-ISSN: 2222-6990 @ 2020 HRMARS

\section{References}

Al-Da'abseh, T., Aljawarneh, N., \& Shwiyat, Z. (2018). Marketing Mix Startegies and Its Impact on Organizational Performance Efficiency in the Jordanian Company for Investment and Supply-Safeway: An Empirical Study. Invention Journal of Research Technology in Engineering \& Management, 2(2), 14-23.

Al-Jawarneh, N. M. S. (2016). Case Study: Business Management School at the Turkish Republic of North Cyprus and how Strategic Thinking and Planning Can Improve the Performance of the Organization to Maintain Stable between Competitors.

Aljawarneh, N. M. S., \& Atan, T. (2018). Linking Tolerance to Workplace Incivility, Service Innovative, Knowledge Hiding, and Job Search Behavior: The Mediating Role of Employee Cynicism. Negotiation and Conflict Management Research, 11(4), 298-320.

Aljawarneh, N., \& Al-Omari, Z. (2018). The Role of Enterprise Resource Planning Systems ERP in Improving Customer Relationship Management CRM: An Empirical Study of Safeway Company of Jordan. International Journal of Business and Management, 13(8), 86-100.

Al-Omari, Z. S., Aljawarneh, N., Davut, S., \& Salah, A. (2018). The Impact of Marketing Mix Elements on Forming Mental Images about Islamic Banks in Jordan: An Empirical Study. OFFICIAL, 12, 54.

Al-Omari, Z., Alomari, K., \& Aljawarneh, N. (2020). The role of empowerment in improving internal process, customer satisfaction, learning and growth. Management Science Letters, 10(4), 841-848.

Al-Qudah, S., Mishael, O. A., Hosam, S., Mohammed A. (2020). The impact of strategic human resources planning on the organizational performance of public shareholding companies in Jordan. Problems and Perspectives in Management, 18(1), 219-230

Alwagfi, A. A., Aljawarneh, N. M., \& Alomari, K. A (2020). Work Ethics and Social Responsibility: Actual and Aspiration. Journal of Management Research, (12)1, 26-36.

Appelbaum, E. (2015). High-performance work practices and sustainable economic growth. EPRN.

Bae, D. G., Hong, J. W., \& Sung, H. A. (2005). U.S. Patent Application No. 10/799,933.

Boer, H., Drejer, A., Minarro-Viseras, E., Baines, T., \& Sweeney, M. (2005). Key success factors when implementing strategic manufacturing initiatives. International Journal of Operations \& Production Management.

Bonn, I. (2001). Developing strategic thinking as a core competency. Management Decision.

Carpenter, M. A., \& Fredrickson, J. W. (2001). Top management teams, global strategic posture, and the moderating role of uncertainty. Academy of Management journal, 44(3), 533545.

Cole, G. A. (2002). Personnel and human resource management. Cengage Learning EMEA.

Dasgupta, S. (2001). Employment security: conceptual and statistical issues (Vol. 10). Geneva: International Labour Office.

Dill, J. S., Morgan, J. C., \& Kalleberg, A. L. (2012). Making "bad jobs" better: The case of frontline healthcare workers. Are bad jobs inevitable, 110-127.

Dionisio, M. A. (2017). Strategic Thinking: The Role in Successful Management. Journal of Management Research, 9(4), 44-57.

Engetou, E. (2017). The impact of training and development on organizational performance. 
Goldman, E. F., \& Casey, A. (2010). Building a culture that encourages strategic thinking. Journal of Leadership \& Organizational Studies, 17(2), 119-128.

Grewal, R., \& Tansuhaj, P. (2001). Building organizational capabilities for managing economic crisis: The role of market orientation and strategic flexibility. Journal of marketing, 65(2), 67-80.

Huselid, M. A., \& Rau, B. L. (1997). The determinants of high performance work systems: crosssectional and longitudinal analyses. In Academy of Management Annual Meetings.

Irtaimeh, H. J., Obaidat, A., \& Khaddam, A. (2016). Strategic Role of Dashboard Application in Enhancing Crisis Management Capabilities in Organizations Field Study on Jordanian Cellular Companies. International Journal of Management Sciences and Business Research.

Malkawi, D. N. M., Baniata, D. M. I., \& Obeidat, D. A. M. (2017). The Impact of E-Government Applications on Decision-Making Effectiveness: Case Study at Jordanian Ministry of Interior-Jordan. International Review of Management and Business Research, 6(1), 172.

Mason, R. O., Dickel, K. E., \& Snyder, N. (1986). Strategic management: A methodological approach. Addison-Wesley.

Mintzberg, H. (1994). Rethinking strategic planning part, I: pitfalls and fallacies. Long range planning, 27(3), 12-21.

Morgan, E. T., Li-Masters, T., \& Cheng, P. Y. (2002). Mechanisms of cytochrome P450 regulation by inflammatory mediators. Toxicology, 181, 207-210.

Norrholm, S. D., Jovanovic, T., Vervliet, B., Myers, K. M., Davis, M., Rothbaum, B. O., \& Duncan, E. J. (2006). Conditioned fear extinction and reinstatement in a human fear-potentiated startle paradigm. Learning \& Memory, 13(6), 681-685.

Nunvi, G. P. (2006). Business Organization, and Management.

Obeidat, A. (2019). IT Adaption with Knowledge Conversion Process (SECI). Management Science Letters, 9(13), 2241-2252

Obeidat, A. M., \& Otibi, G. A. (2015). The impact of knowledge sharing tools on levels of organizational learning (Field Study on Jordanian Commercial Banks). Australian Journal of Basic and Applied Sciences, 9(5), 253-267.

Pant, R. P., \& Pant, V. (2000). Common fixed points under strict contractive conditions. Journal of Mathematical Analysis and Applications, 248(1), 327-332.

Patel, P. C., \& Conklin, B. (2012). Perceived labor productivity in small firms-The effects of highperformance work systems and group culture through employee retention. Entrepreneurship Theory and Practice, 36(2), 205-235.

Ployhart, R. E. (2006). Staffing in the 21st century: New challenges and strategic opportunities. Journal of management, 32(6), 868-897.

Rao, P. S. V., Balaji, and Girish, K. (2017). "A Study on Factors that Influence Power Struggle and Peer Relation." (2017).

Saffar, N., \& Obeidat, A. (2020). The effect of total quality management practices on employee performance: The moderating role of knowledge sharing. Management Science Letters, 10(1), 77-90.

Solutions, I., \& Belt, G. B. (2017). THE IMPACT OF STRATEGIC MANAGEMENT AND STRATEGIC THINKING APPROACHES ON BUSINESS PERFORMANCE OF COMPANIES OPERATING IN THE RETAIL INDUSTRY. 
Steptoe-Warren, G., Howat, D., \& Hume, I. (2011). Strategic thinking and decision making: literature review. Journal of Strategy and Management.

Timiyo, A. J. (2014). High Performance Work Practices: One best-way or no best-way. IOSR Journal of Business and Management, 16(6), 8-14.

Timiyo, A. J. (2014). High Performance Work Practices: One best-way or no best-way. IOSR Journal of Business and Management, 16(6), 8-14.

Ulijn, J., O'Hair, D., Weggeman, M., Ledlow, G., \& Hall, H. T. (2000). Innovation, Corporate Strategy, and Cul tural Context: What Is the Mission for International Business Communication. The Journal of Business Communication (1973), 37(3), 293-316.

Zabriskie, N. B., \& Huellmantel, A. B. (1991). Developing strategic thinking in senior management. Long Range Planning, 24(6), 25-32. 